\title{
Working Memory Versus Inhibitory Control: Sebuah Kajian Neuropsikologi Mengenai Peran Informasi Tidak Relevan
}

\author{
Working Memory versus Inhibitory Control: A \\ Neuropsycholoical Study of Irrelevant Information
}

\author{
Nani Restati Siregar \\ Fakultas Keguruan dan Ilmu Pendidikan, Jurusan Psikologi, Universitas Halu Oleo
}

Submitted 4 February 2020 Accepted 18 May 2020 Published 28 June 2021

\begin{abstract}
Previous studies reported that working memory (WM) plays an important role in ignoring irrelevant information. Other studies reported that inhibition control (IC) inhibits irrelevant stimuli and unwanted responses. Both WM and IC contribute to irrelevant information. WM and IC are two different cognitive constructs. However, how is their dynamic in responding to irrelevant information? The current literature study was to describe: (a) the concepts of working memory (WM) and inhibition control (IC); (b) neural mechanisms of irrelevant information; (c) neural mechanisms of working memory and inhibitory control on irrelevant information. The literature study concluded that working memory capacity and inhibitory control capacity are cognitive control mechanism on irrelevant information. Prefrontal cortex is activated when working memory and inhibitory control are processing irrelevant information. However, working memory only notes then ignores the irrelevant information, while the inhibition of irrelevant information was done by inhibitory control. Specifically, when high performance of working memory is needed, inhibitory control strengthens the working memory performance.
\end{abstract}

Keywords: inhibitory control; irrelevant information; neuropsychology; working memory

Abstrak. Studi terdahulu melaporkan bahwa working memory (WM) memainkan peran penting dalam mengabaikan informasi tidak relevan sehingga hanya informasi relevan saja yang bekerja pada sistem working memory. Studi lainnya melaporkan bahwa inhibition control (IC) diperlukan untuk menghambat stimulus yang tidak relevan dan menghambat respons yang tidak dihendaki. WM dan IC adalah dua konstrak kognitif yang berbeda dan keduanya memberikan respons pada informasi tidak relevan. Namun, bagaimanakah dinamika kedua konstrak tersebut merespons informasi tidak relevan? Studi literatur kali ini bermaksud untuk menguraikan: (a) konsep mengenai working memory (WM) dan inhibitory control (IC); (b) mekanisme neural pada informasi yang tidak relevan; (c) mekanisme neural working memory dan inhibitory control pada informasi yang tidak relevan. Studi literatur ini menyimpulkan bahwa kapasitas working memory dan inhibitory control merupakan mekanisme kontrol kognitif terhadap informasi tidak relevan. Prefrontal cortex pada otak teraktivasi ketika working memory dan inhibitory control merespons informasi tidak relevan. Namun, working memory hanya menandai atau mengabaikan informasi tidak relevan sementara inhibitory control menghambat informasi tidak relevan. Inhibitory control memperkuat dan meningkatkan kinerja working memory ketika informasi tidak relevan tidak hanya cukup untuk diabaikan saja.

Kata kunci: informasi tidak relevan, inhibitory control; neuropsikologi; working memory 


\section{Pengantar}

Kemampuan individu dalam memahami dan melaksanakan tugas tertentu adalah bergantung pada kapasitas kognitif yang dimilikinya (Künstler et al., 2018; Roets et al., 2008). Kapasitas kognitif bekerja secara berbeda bergantung pada apakah tugas yang dilakukan itu bersifat sederhana atau kompleks, misalnya melibatkan stimulus atau informasi tidak relevan (Strobel et al., 2018). Informasi tidak relevan adalah informasi yang bersifat mengganggu perhatian dan sengaja dihadirkan pada suatu tugas tertentu, misalnya ketika siswa harus membaca dan memaknai semua kalimat pada soal cerita padahal beberapa kalimat yang ada merupakan pengecoh (Swanson, 2016; Swanson, 2015). Hadirnya informasi tidak relevan, baik dalam tugas akademik maupun aktivitas dalam kehidupan sehari-hari, misalnya pengambilan keputusan berdasarkan berpikir logis menuntut kerja kognitif yang lebih kompleks dan berdampak pada upaya penggunaan strategi pemecahan yang tepat (Rop et al., 2018). Strategi pemecahan juga bergantung pada tipe tugas yang dihadapi, misalnya salah satu tugas akademik matematika, yakni strategi pemecahan non-rutin lebih menstimulasi beban kinerja kognitif (Zhang et al., 2017) dibandingkan strategi rutin yang mana kedua tipe tugas tersebut melibatkan informasi tidak relevan. Individu dengan kapasitas kognitif yang terbatas dapat dilatih agar mampu menghambat pikiran dan respons yang tidak dihendaki atau tidak relevan serta lebih efisien dan efektif dalam memilih dan memproses informasi relevan berdasarkan performansi working memory (Simon et al., 2016), dan inhibitory control (Martyr et al., 2019). Semakin kompleks suatu tugas maka semakin kuat informasi tidak relevan mengacaukan atensi. Working memory dan inhibition control keduanya merupakan kapasitas kognitif yang terlibat dalam proses berpikir kompleks (Greiff et al., 2015; Valle et al., 2019).

Penelitian terdahulu melaporkan bahwa working memory berkontribusi signifikan terhadap kemampuan atensi dalam melakukan seleksi pada informasi relevan dengan menandai atau mengabaikan informasi tidak relevan (Pimperton \& Nation, 2010; Swanson et al., 2013; Swanson et al., 2012). Di sisi lain, inhibitory control juga menunjukkan pengaruhnya sebagai komponen fungsi eksekutif yang menghambat pikiran dan respons pada informasi tidak relevan (Brookman-Byrne et al., 2018). Tampaknya perlu secara jelas dibedakan antara mengabaikan dan menandai informasi tidak relevan pada tugas working memory (WM) dan menghambat informasi tidak relevan pada inhibitory control (IC) ataukah antara mengabaikan dan menghambat informasi merepresentasikan fungsi kinerja kognitif yang sama? Artinya, apakah peran WM dan IC berbeda ataukah masingmasing salah satu diantara keduanya masih merupakan bagian dari yang lainnya? Studi terdahulu melaporkan bahwa gagalnya working memory memproses informasi relevan disebabkan oleh terganggunya perkembangan inhibitory control sehingga fungsi mendukung working memory untuk menghambat informasi tidak relevan tidak tercapai (Chiappe et al., 2000; Lustig et al., 2010). WM dan IC merupakan mekanisme kontrol kognitif yang memainkan peran penting dalam merespons informasi tidak relevan (Fallon et al., 2019; Mertes et al., 2016) juga berkontribusi pada keterampilan berpikir tingkat tinggi, misalnya pemecahan masalah. 
Ada mekanisme neural yang terlibat dalam hal merespons informasi tidak relevan yakni keterlibatan working memory dan inhibitory control. Otak dapat mengenal, menandai dan menghambat informasi tidak relevan (van Moorselaar \& Slagter, 2019). Jalur frontoparietal adalah jalur lateral di otak merupakan mekanisme neural yang terlibat saat hadirnya informasi tidak relevan ketika tugas working memory dilakukan (Nasr et al., 2008). Di sisi lain, meknisme neural fronto-temporal merupakan peran inhibitory control terhadap pengaturan diri untuk berperilaku (Vara et al., 2014). Jalur fronto-parietal umumnya terkait dengan tugas kognitif sedangkan fronto-temporal merupakan jalur neural yang merepresentasikan tugas kontrol emosi. Starr (2011) melaporkan bahwa informasi tidak relevan atau stimulus yang mengandung interferensi berasal dari medial temporal lobe (MTL), sedangkan medial prefrontal cortex (MPFC) melakukan kontrol terhadap interferensi tersebut. Starr (2011) menambahkan bahwa fronto-medial temporal pathway atau jalur MPFC - MTL melalui anterior cingulate cortex (ACC) merupakan model yang ditemukan untuk jalur inhibiton control (IC). Cingulate cortex terkoneksi dengan orbitofrontal cortex terkait dengan adanya reward dan menerima informasi spasial yang berasal dari area parietal cortex serta anterior cingulate cortex merepresentasikan tindakan yang diharapkan (Rolls, 2019).

Studi literatur ini bertujuan menguraikan tentang: (a) konsep working memory dan inhibitory control; (b) mekanisme neural dari informasi tidak relevan (c) mekanisme neural working memory dan inhibitory control pada informasi tidak relevan.

\section{Konsep Working Memory dan Inhibitory Control}

Konsep Working Memory

Memori atau ingatan menurut Baddeley (2012) terdiri atas tiga jenis, yakni: working memory, short term memory dan long term memory. Working memory merupakan evolusi dari konsep short term memory (STM), dan keduanya sering digunakan saling bertukar untuk menjelaskan hal yang sama terkait dengan penyimpanan informasi. Namun, Baddeley (2012) menegaskan bahwa STM lebih sederhana karena hanya terkait dengan penyimpanan informasi yang bersifat sementara saja. Working memory merupakan kombinasi antara penyimpanan sementara dan manipulasi informasi (Crone et al., 2006). Sedangkan, long term memory (LTM) merupakan penyimpanan informasi yang lebih lama dibanding working memory dan STM. LTM juga dapat mempengaruhi kinerja working memory (Artuso \& Palladino, 2019; Schurgin et al., 2018). Baddeley lebih lanjut mengemukakan model working memory sebagaimana Gambar 1. 


\section{Gambar 1}

Working Memory Secara Skematis Kaitannya dengan Central Executive, Short Term Memory, Episodic Buffer dan Long Term Memory (Baddeley, 2012).

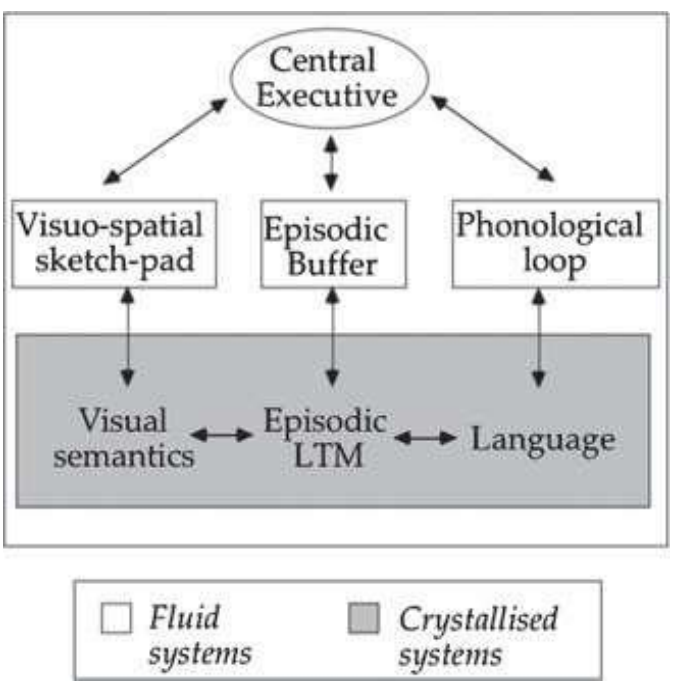

Gambar 1 menunjukkan central executive berperan terhadap semua komponen kognitif di bawahnya, namun central executive juga dipengaruhi oleh ketiga komponen tersebut. Central executive berkontribusi dalam pembelajaran asosiatif (Sasaki, 2009) dan pembelajaran asosiatif merupakan proses kognitif tingkat tinggi (De Houwer et al., 2016). Sementara informasi visual diproses pada visuo-spatial sketch-pad, misalnya menggunakan strategi menggambar untuk merepresentasikan informasi yang berasal dari ingatan (Fastame, 2020). Komponen episodic buffer mengintegrasikan unit-unit dari informasi verbal dengan phonological loop terkait dengan bahasa (Rudner \& Rönnberg, 2008) juga unit dari visual dan spasial (Plancher et al., 2018). Working memory memengaruhi kemampuan fluid atau fluid ability (Little et al., 2014) untuk tugas-tugas yang bersifat kebaruan dan kompleks (Yang \& Tang, 2011), misalnya tugas kognitif penalaran (Singh et al., 2018). Di sisi lain, crystallised ability atau kemampuan kristal secara neuropsikologi juga dipengaruhi oleh working memory ketika memperoleh informasi baru, menyimpan sementara dan memanipulasi informasi tersebut. Informasi dan pengetahuan umum yang tersimpan dalam ingatan jangka panjang serta hasil belajar keterampilan baru diimplementasikan kembali yang disebut dengan kemampuan kristal (Moehring et al., 2018). Dengan demikian baik kemampuan fluid dan kemampuan kristal keduanya didukung oleh kinerja working memory.

Konsep working memory menurut Shah \& Miyake (1999) merangkum dari berbagai ahli yang memberikan metafora untuk working memory, antara lain: kotak atau tempat, ruang kerja atau papan hitam, energi mental atau sumber daya dan metafora sulap. Metafora-metafora yang diungkap tersebut menginformasikan bahwa working memory merupakan energi mental. Energi mental yang dimaksud adalah kekuatan kognisi dalam hal mengingat (memory), menyimpan dan memanipulasi stimulus sebagaimana yang telah diuraikan oleh Baddeley (2012). Perbedaan individu pada hasil belajar akademik 
mengindikasikan kapasitas working memory yang berbeda (Karlsson et al., 2019; Laing et al., 2019). Cowan (2014) menyebutkan bahwa working memory dalam arah perkembangan kognitif meliputi; (a) berbasis kapasitas; (b) berbasis pengetahuan; (c) berbasis strategi dan kecepatan memproses; (d) dapat ditingkatkan kapasitasnya melalui latihan; (e) terlibat dalam proses belajar.

Kapasitas working memory selain meng-update dan me-maintenance informasi relevan (Manza et al., 2014; Wilhelm et al., 2013) yang merupakan target juga mengabaikan informasi tidak relevan. Hal ini dilakukan agar performansi working memory menjadi akurat dibandingkan jika masih terdapatnya stimulus yang tidak dihendaki (Endres et al., 2015). Namun, tugas meng-update dan me-maintenance informasi relevan lebih utama dibandingkan mengabaikan informasi tidak relevan. Fallon et al. (2018) melaporkan bahwa memfokuskan atensi pada working memory lebih ditujukan pada meng-update dan me-maintenance informasi relevan dibanding mengabaikan informasi tidak relevan. Temuan ini dapat diasumsikan bahwa performansi memfokuskan perhatian pada informasi relevan menunjukkan informasi tidak relevan bukan merupakan tujuan dan target utama pada kinerja working memory. Cowan dan Morey (2016) menjelaskan bahwa kemampuan mengingat objek target termasuk menunjukan efisiensi mengabaikan informasi tidak relevan. Para ahli melaporkan bahwa terdapat mekanisme yang mengambat informasi tidak relevan dan mengaktivasi area korteks otak selama working memory melakukan encoding pada stimulus relevan (Ahveninen et al., 2017; Toepper et al., 2010). Mekanisme tersebut diasumsikan sebagai kinerja kognitif lain yang mendukung performansi tinggi working memory karena fokus perhatian hanya pada stimulus target, yakni informasi relevan. Di dalam hal ini semakin fokus perhatian diberikan kepada stimulus target selama pengkodean maka semakin menstimulasi kinerja kognitif lainnya untuk melemahkan pengaruh informasi tidak relevan (Bocincova \& Johnson, 2019). Gaspelin dan Luck (2017) mempertegas adanya mekanisme kontrol kognitif yang berperan menghambat informasi tidak relevan dan peran ini sangat kuat karena bertujuan memastikan informasi tersebut agar tidak masuk pada atensi saat kinerja working memory memproses stimulus target.

Berdasarkan uraian tersebut disimpulkan bahwa konsep working memory terhadap informasi tidak relevan adalah menandai dan mengabaikan serta bukan menghambat informasi tidak relevan. Fokus secara penuh pada stimulus target (informasi relevan) menjadikan performansi working memory efisien dalam memberikan respons yang tepat. Respons yang akurat juga didukung oleh mekanisme kognitif lainnya yang mendukung performansi working memory.

\section{Inhibitory Control}

Para ahli menyatakan bahwa terdapat komponen kognitif untuk menghambat informasi tidak relevan dari working memory (Pimperton \& Nation, 2010). Zanto dan Gazzaley (2009) melaporkan bahwa kinerja working memory ditentukan oleh kemampuan menyeleksi informasi relevan disaat informasi tidak relevan berupaya mengacaukan atensi. Hal ini dapat saja dimaknai bahwa terdapat komponen kognitif lain yang melakukan tugas 
menghambat informasi tidak relevan sehingga working memory menghasilkan performansi yang tinggi pada tugas meng-update dan memanipulasi informasi relevan. Temuan lain melaporkan bahwa working memory (WM) dan inhibitory control (IC) masing-masing memiliki tugas yang berbeda yakni, WM terkait dengan proses memelihara, meng-update dan menyimpan ingatan, sedangkan IC adalah menghambat respons yang tidak diharapkan dan kontrol terhadap interferensi stimulus (Maraver et al., 2016). Interferensi pada stimulus dimaknai sebagai informasi yang mengganggu atau mengacaukan kinerja WM, bahkan tugas yang bersifat kompleks, misalnya dual task (visual dan auditory) dapat membebani performansi WM (Heathcote et al., 2015).

Kerangka teori inhibitory control terdiri dari attentional inhibition dan response inhibition adalah konstrak laten yang independen, namun relatif masih terkait dengan working memory (Tiego et al., 2018). Inhibitory control merupakan konstruk terpisah dan independen dari working memory sejak memasuki masa anak akhir (Shing et al., 2010). Ini menunjukkan bahwa kedua komponen kognitif tersebut terpisah satu dengan lainnya seiring bertambahnya usia anak. Pada individu dewasa, dilaporkan bahwa kualitas kontrol inhibisi mencerminkan perfomansi working memory terkait bertambahnya usia (Zeinti \& Kliegel, 2007). Valle et al. (2019) menyatakan inhibitory control berperan menghambat ingatan tidak sadar (unconscious memory) terkait dengan tugas pemecahan masalah. Tugas pemecahan masalah dapat berupa perilaku penyesuaian sosial untuk menghindari stres (Roos et al., 2017) dan pemecahan masalah akademik (Blair et al., 2008). Berdasarkan uraian tersebut, disimpulkan bahwa inhibitory control (IC) berperan pada proses menghambat stimulus atau interferensi yang bersifat mengganggu dalam proses pemecahan masalah baik secara akademik maupun non akademik.

Model inhibitory control lainnya dirangkum oleh Meyer dan Bucci (2016) yakni inhibisi reaktif dan proaktif yang mekanisme kerjanya berasal dari sirkuit basal ganglia. Basal ganglia berada pada area subkorteks otak yang mengontrol gerakan motorik manusia serta terkoneksi dengan otak korteks. Inhibisi proaktif dianggap dapat mengendalikan inhibisi reaktif. Di sisi lain, Inhibitory control sangat terkait dengan kontrol reaksi yang berulang ketika nilai stimulus reward semakin positif mengarahkan perilaku. Kondisi ini menyebabkan meningkatnya aktivasi jalur orbitofrontal dan cingulate namun ketika latihan kontrol inhibisi diberikan maka mengaktivasi jalur temporo - parietal (Pretto et al., 2019). Ada hal yang unik dari jalur aktivasi di otak antara working memory dan inhibitory control terhadap informasi tidak relevan. Working memory telah disebutkan sebelumnya bahwa semakin meningkat respons stimulus visual semakin meningkatkan aktivasi area fronto-parietal. Sedangkan, stimulus yang terkait dengan respons memperoleh rasa senang, misalnya semakin kuat untuk memperoleh hadiah maka semakin meningkatkan aktivasi jalur orbitofrontal dan cingulate. Kedua jalur ini diketahui terkoneksi langsung dengan amigdala dan struktur medial temporal serta merupakan fungsi dari emosi dan memori.

Gambar berikut adalah jalur orbitofrontal dan cingulate cortex yang merupakan representasi jalur respons emosi, yakni penampang otak yang menunjukkan area prefrontal cortex (PFC) yang terdiri dari sub area lateral, yakni terkait dengan tugas 
kognitif dan sub area medial yang terkoneksi langsung dengan amigdala di area subkorteks.

\section{Gambar 2}

Permukaan Lateral PFC (kiri) dan Permukaan Medial (kanan)

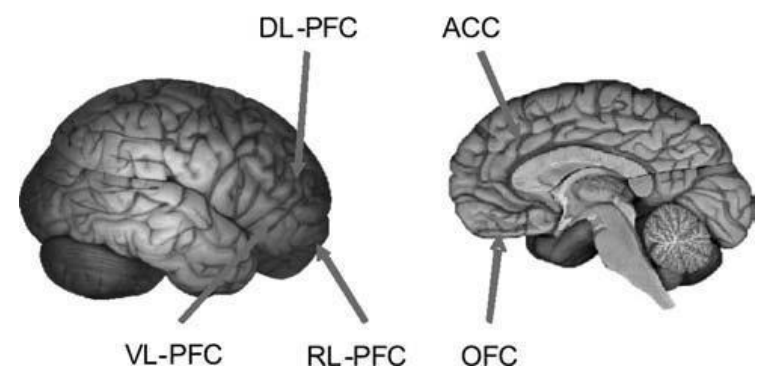

Catatan. Anterior Cingulate Cortex (ACC); Dorsolateral Prefrontal Cortex (DL-PFC); Orbitofrontal Cortex (OFC); Rostrolateral Prefrontal Cortex (RL-PFC); Ventrolateral Prefrontal Cortex (VL-PFC) (Zelazo \& Lee, 2010).

Konsep inhibitory control tidak hanya berperan untuk kontrol respons yang tidak diharapkan saja, namun juga terhadap pikiran dari informasi tidak relevan. Hal ini sejalan dengan studi yang melaporkan bahwa tugas menginhibisi ingatan tidak menyebabkan terjadinya inhibisi perilaku (Nooren \& MacLead, 2015; Preuss et al., 2019). Temuan para ahli tersebut memberikan informasi bahwa inhibitory control selain berkontribusi pada pikiran tidak relevan juga menghambat respons yang tidak dikehendaki. Perspektif lain menyebutkan bahwa inhibitory control dapat menginhibisi persepsi, kognitif dan respons yang tidak diharapkan serta berkontribusi pada penalaran (Aydmune et al., 2019). Inhibitory control juga merupakan sistem kontrol kognitif dalam menghambat informasi tidak relevan (Blumenfeld \& Marian, 2014). Namun, kontrol kognitif lain yakni working memory menampilkan performansi meregulasi perilaku impulsif (Brookset al., 2017). Pertanyaan yang muncul kemudian apakah inhibitory control bergantung pada working memory? Studi terdahulu telah menyebutkan bahwa inhibitory control merupakan konstrak laten yang terdiri dari beberapa dimensi. Inhibitory control adalah suatu sistem neuropsikologi yang seharusnya independen dari working memory. Baik inhibitory control dan working memory keduanya mengaktivasi area otak medial dan lateral prefrontal cortex terkait informasi tidak relevan. Anterior cingulate cortex yang terkoneksi dengan area korteks lainnya mendasari fungsi menghambat informasi tidak relevan yang merupakan peran dari inhibitory control.

Berdasarkan uraian tersebut konsep inhibitory control merupakan mekanisme neuropsikologi yang secara neural mengaktivasi area prefrontal cortex untuk menghambat informasi tidak relevan. Mekanisme inhibitory control ini secara independen mendukung tugas working memory agar performansinya menjadi lebih baik. 


\section{Mekanisme Neural: Informasi Tidak Relevan; Working Memory dan Inhibitory Control terhadap Informasi tidak Relevan.}

Mekanisme Neural Informasi tidak Relevan

Informasi tidak relevan atau disebut juga sebagai stimulus pengganggu yang bukan target berpotensi mengacaukan performansi kognitif dalam melaksanakan tugasnya (Wais \& Gazzaley, 2011). Informasi tersebut antara lain dapat berupa suara (Oswald et al., 2000); stimulus visual dan spasial (Huang et al., 2009; Strobel et al., 2018). Informasi relevan merupakan informasi penting yang diproses dan dipertahankan di dalam pikiran sehingga menghasilkan respons atau tindakan tepat (Michal et al., 2014). Siebert dan Ellis (1991) melaporkan bahwa performansi kognitif ditentukan dari bagaimana individu sukses mengabaikan informasi tidak relevan dengan memproses informasi relevan. Berdasarkan hal tersebut, dianggap penting mengetahui mekanisme neural yang mendasari pemrosesan informasi relevan dan respons neural terhadap informasi tidak relevan.

Berikut adalah hasil-hasil studi yang melaporkan mengenai mekanisme jalur neural yang terlibat dalam informasi tidak relevan.

\section{Tabel 1}

Area Otak yang Teraktivasi pada Informasi tidak Relevan

\begin{tabular}{|c|c|c|c|}
\hline Penulis & Judul Artikel & Subjek & $\begin{array}{l}\text { Area Otak yang } \\
\text { Teraktivasi }\end{array}$ \\
\hline $\begin{array}{l}\text { Wei et al. } \\
\text { (2018) }\end{array}$ & $\begin{array}{l}\text { Differential brain mechanism for processing } \\
\text { distracting information in task-relevant and - } \\
\text { irrelevant dimensions in visual search. }\end{array}$ & Dewasa & fronto-parietal area \\
\hline $\begin{array}{l}\text { Polk et al. } \\
\text { (2008) }\end{array}$ & $\begin{array}{l}\text { Attention Enhances the Neural Processing of } \\
\text { Relevant Features and Suppresses the Process- } \\
\text { ing of Irrelevant Features in Humans: A } \\
\text { Functional Magnetic Resonance Imaging Study } \\
\text { of the Stroop Task. }\end{array}$ & Dewasa & $\begin{array}{l}\text { Area posterior dari } \\
\text { otak }\end{array}$ \\
\hline $\begin{array}{l}\text { Milham et } \\
\text { al. (2002) }\end{array}$ & $\begin{array}{l}\text { Attentional control in the aging brain: Insight } \\
\text { from fMRI study of the stroop task. }\end{array}$ & Dewasa & $\begin{array}{l}\text { Ventral visual } \\
\text { processing (temporal } \\
\text { cortex) dan anterior } \\
\text { inferior prefrontal } \\
\text { cortex. }\end{array}$ \\
\hline $\begin{array}{l}\text { Egner et al. } \\
\text { (2006). }\end{array}$ & $\begin{array}{l}\text { Separate conflict - specific cognitive control } \\
\text { mechanism in the human brain. }\end{array}$ & Dewasa & $\begin{array}{l}\text { Superior parietal lobule } \\
\text { (stroop task) }\end{array}$ \\
\hline
\end{tabular}

Uraian tersebut menunjukkan jalur neural yang terlibat dalam merespons informasi tidak relevan, yakni pada area otak korteks. Area ini berperan pada berpikir tingkat tinggi yakni, kreativitas (Abdul Hamid et al., 2019). Fronto - parietal merupakan jalur neural yang terlibat dalam proses kognitif tingkat tinggi (Almaric \& Dehaene, 2016; Kesler et al., 2011). Makin kompleks dan rumit proses mental yang terjadi di dalam otak semakin melibatkan intervensi dari informasi tidak relevan. Intervensi tersebut dapat berasal dari area 
subkorteks yakni terkait dengan pengetahuan yang telah ada sehingga diperlukan peran korteks yang dapat menjaga kualitas berpikir kompleks tersebut (Schilling et al., 2013).

Area subkorteks atau wilayah a-sadar dari otak juga memainkan peran penting dalam mendukung kinerja otak korteks. Yamagato et al. (2004) melaporkan bahwa individu yang mengalami stroke pada area subkorteks menyebabkan disfungsi pada jalur fronto-subkorteks yang merupakan mekanisme sistem neural yang memproses kejadian baru. Mekanisme jalur fronto-subkorteks istilah lainnya adalah mekanisme neural top down di mana dalam kondisi normal dan sehat mekanisme lobus frontalis memberikan sinyal "stop" kepada wilayah subkorteks saat menilai akan terjadi reaksi emosi yang tidak tepat. Mekanisme kontrol top - down ini berkontibusi dalam memproses informasi situasional mengenai individu lain dalam konteks sosial (Brosch et al., 2013).

Gambar 3 menjelaskan bagaimana mekanisme neural kontrol top - down yakni dari korteks ke subkorteks dan bagaimana kontrol tersebut menjadi lemah sehingga sinyal "stop" dari otak korteks ke subkortkes tidak dapat dilakukan.

\section{Gambar 3}

"Top-Down Signaling" Prefrontal Cortex pada Area Sub Cortical.
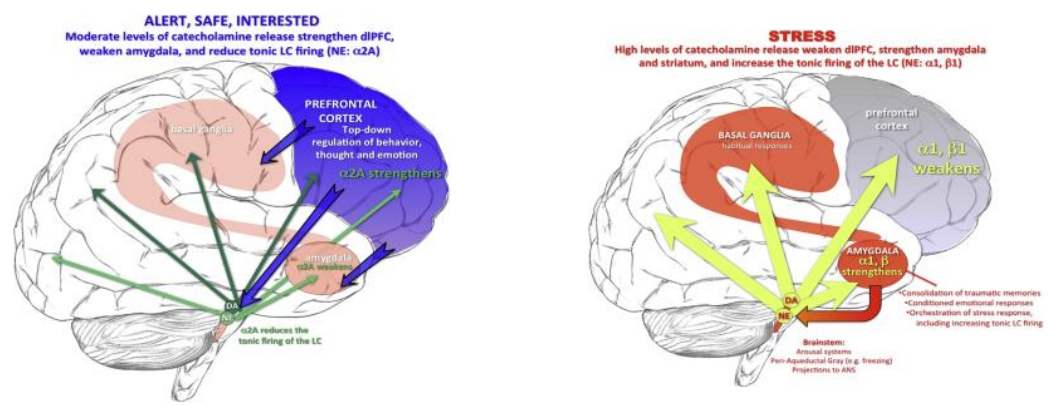

Catatan. Bagian kiri menunjukkan prefrontal cortex memberikan sinyal "stop" pada reaksi subkorteks dan bagian kanan adalah kontrol prefrontal cortex yang lemah sehingga berdampak negatif bagi individu, misalnya stress. (Arnsten et al., 2015).

\section{Mekanisme Neural Working Memory terhadap Informasi Tidak Relevan}

Informasi yang diproses di dalam sistem working memory hanya informasi yang sesuai target atau informasi relevan. Informasi relevan yang disimpan dan dimanipulasi dalam sistem tersebut setelah melewati proses mengabaikan informasi tidak relevan. Mekanisme memproses informasi relevan dan respons terhadap informasi tidak relevan mengaktivasi jalur di otak yang diuraikan sebagaimana pada Tabel 2 berikut. 
Tabel 2

Performansi Working Memory pada Informasi Tidak Relevan dan Area Otak yang Teraktivasi.

\begin{tabular}{|c|c|c|c|}
\hline Penulis & Pengukuran & Subyek & Area Otak yang Teraktivasi \\
\hline $\begin{array}{l}\mathrm{Na} \text {, et. al. } \\
(2000)\end{array}$ & $\begin{array}{l}\text { Verbal WM task; Visual WM } \\
\text { task }\end{array}$ & Dewasa & $\begin{array}{l}\text { Inferior frontal cortex. Inferior } \\
\text { dan superior parietal cortex serta } \\
\text { temporal gyrus }\end{array}$ \\
\hline $\begin{array}{l}\text { Baier, et. al. } \\
\quad(2010)\end{array}$ & $\begin{array}{l}\text { Voxelwise lesion-behavior } \\
\text { brain mapping (VLBM) }\end{array}$ & Dewasa & $\begin{array}{l}\text { Basal ganglia-prefrontal cortex } \\
\text { model }\end{array}$ \\
\hline $\begin{array}{l}\text { Derrfuss et } \\
\text { al. (2017) }\end{array}$ & a delayed match-to-sample task & Dewasa & Posterior prefrontal cortex \\
\hline $\begin{array}{l}\text { Clapp et al. } \\
\text { (2010) }\end{array}$ & $\begin{array}{l}\text { tugas yag tediri dari distraktor } \\
\text { dan non-distraktor }\end{array}$ & Dewasa & $\begin{array}{l}\text { Middle frontal gyrus dan visual } \\
\text { cortex }\end{array}$ \\
\hline $\begin{array}{l}\text { Burhan, } \\
\text { et.al. (2016) }\end{array}$ & $\begin{array}{l}\text { visual WM by using E-Prime } 2 \\
\text { (psychology software) }\end{array}$ & Dewasa & $\begin{array}{l}\text { amygdala, anterior cingulate } \\
\text { cortex, dan frontal area }\end{array}$ \\
\hline
\end{tabular}

Kesimpulan berdasarkan uraian tersebut bahwa aktivasi otak meliputi baik area korteks maupun subkorteks (misalnya amigdala) ketika terpapar oleh informasi atau stimulus yang tidak relevan. Area otak tersebut memainkan peran penting baik dalam memfilter, menandai maupun mengabaikan informasi tidak relevan. Anterior cingulate cortex teraktivasi ketika stimulus visual memicu respons emosi yang berasal dari amigdala sebagaimana yang ditunjukkan pada tabel tersebut. Namun, di dalam penelitian tersebut tidak disebutkan bahwa tugas working memory adalah menandai atau mengabaikan informasi tidak relevan, melainkan bertujuan untuk mengetahui apakah subjek penelitian tersebut yang mengalami gangguan kognitif menunjukkan peran working memory yang memproses stimulus takut. Model kinerja working memory didasarkan pada plastisitas sinap yang terdapat antar neuron, selain berperan aktif pada area korteks otak atau yang disebut dengan wilayah sadar juga terlibat pada sub korteks atau wilayah bawah sadar (Eriksson et al., 2015).

Luck dan Vogel (2013) menyatakan bahwa suatu kapasitas visual working memory dalam merespons informasi relevan dan mengabaikan informasi tidak relevan berdampak pada efisiensi dalam menggunakan kapasitas memori tersebut. Deco dan Rolls (dalam Luck \& Vogel, 2013) menguraikan mekanisme neural yang terjadi saat working memory memproses stimulus visual. 


\section{Gambar 4.}

Representasi Neural terhadap Tiga Kompartemen Sel (Kelompok pada Neuron yang Mengkoding Objek Terpisah di dalam Visual Working Memory/VWM).

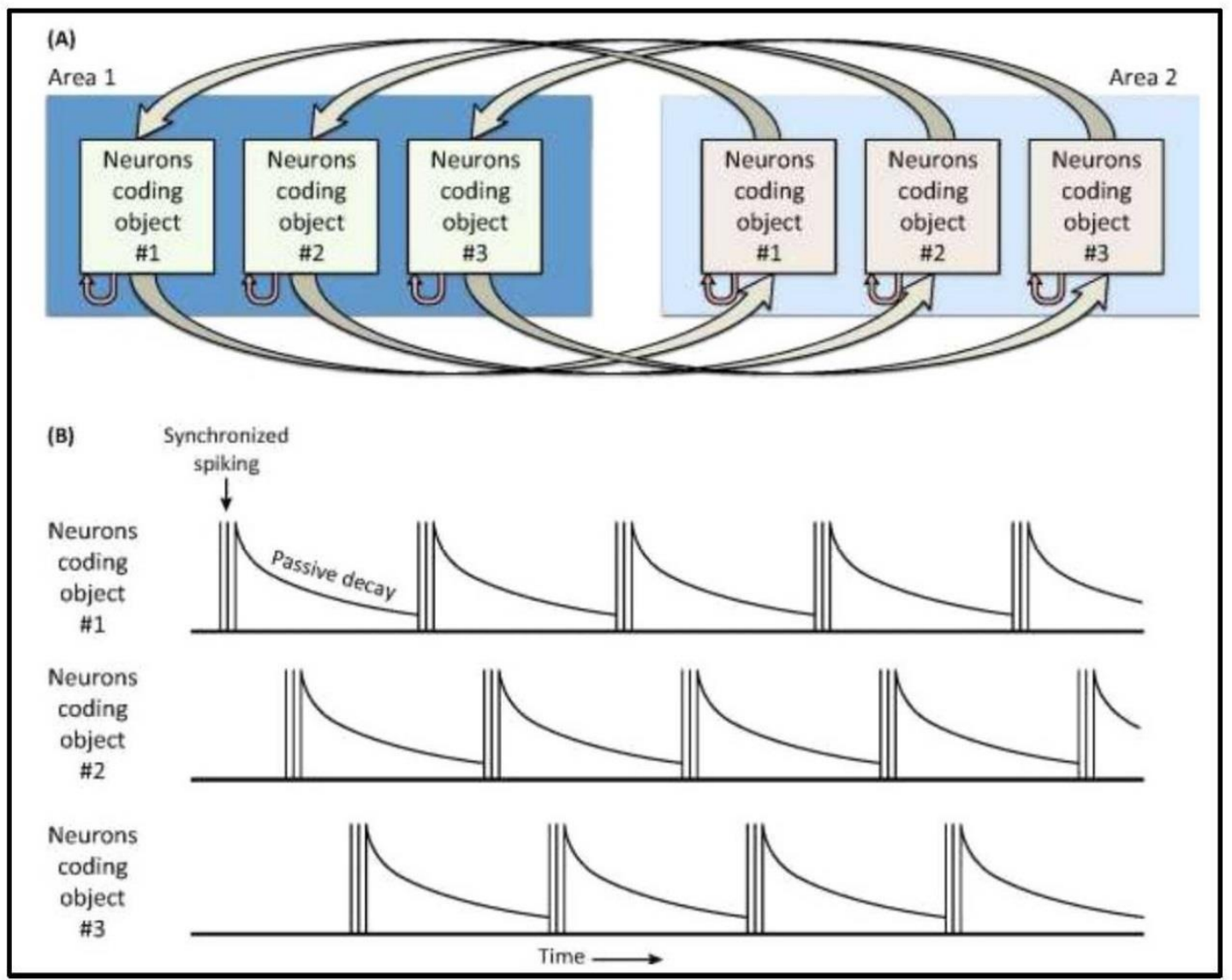

Catatan. Masing-masing kompartemen sel berasal dari satu atau lebih area korteks. Pada beberapa model neuron direkrut pada kompartemen sel tertentu untuk merepresentasikan fitur pada objek yang dikodekan dan neuron tersebut teralokasikan pada kompartemen sel yang berbeda bergantung pada informasi yang tersimpan dalam memory. (A) bagian ini menunjukkan kelompok neuron mengkoding objek yang diberikan dalam satu loop di dalam area yang sama (tanda panah bentuk U) dan loop antar area (panah menuju area 2). Hubungan tersebut menyebabkan aktivitas terjaga dan aktivitas bolak balik antar neuron (di dalam area dan antar area). Area otak yang terlibat yakni inferotemporal dan prefrontal cortex, sekalipun demikian banyak area berbeda di otak yang tersinkron melalui model ini. (B) bagian ini menunjukkan neuron dalam satu kompartemen sel (ditunjukkan pada garis vertikal) yang mengalami lonjakan dan kemudian mengalami penurunan. Perbedaan lonjakan kompartemen sel di waktu yang berbeda akan meminimalkan interferensi diantara kompartemen sel tersebut. Kompartemen sel harus kembali mengalami lojakan sebelum terlalu lama mengalami penurunan. Cara ini dilakukan agar tetap memelihara dan menjaga representasi visual WM. (Deco \& Rolls, dalam Luck \& Vogel, 2013).

Berdasarkan dua model mekanisme neural representasi visual working memory (WM) tersebut nampak bahwa model pertama mempertahankan memori dengan cara mengalirkan informasi dari satu neuron ke neuron lainnya serta mengalirkan kembali 
pada neuron awal. Ini semacam membuat suatu jalur ikatan kuat antar neuron yang mana bertujuan melestarikan informasi yang diperoleh. Sedangkan, pada model lainnya mekanisme neural visual WM sangat kuat mempertahankan informasi. Ini dapat terjadi karena di awal aktivitas terdapat atensi penuh yang dilakukan oleh individu namun tidak bertahan lama karena secara perlahan hilang sehingga mengakibatkan ketidakmampuan merepresentasikan informasi lagi. Oleh karena itu, diperlukan lonjakan sel lagi sebelum batas waktu habis dan mengalami interferensi dengan stimulus lain. Mekanisme neural ini membuktikan bahwa performansi working memory dibatasi oleh jumlah tugas dan waktu untuk menyelesaikan tugas tersebut. Ini mungkin juga dapat menjadi usulan asumsi bahwa informasi tidak relevan bukan hanya diawal saat menangkap, menyimpan dan memanipulasi informasi di dalam working memory namun juga selama jarak waktu memanipulasi informasi atau stimulus maka interferensi stimulus lain dapat saja hadir dan kembali mengganggu informasi yang menjadi target.

\section{Mekanisme Neural Inhibitory Control}

Inhibitory control sesuai dengan tujuannya tidak hanya menghambat perilaku yang tidak dihendaki secara sosial dan normatif namun juga menghambat pikiran yang tidak relevan. Studi terdahulu melaporkan mengenai mekanisme area otak yang terlibat dalam menghambat informasi tidak relevan sebagai berikut:

\section{Tabel 3}

Performansi Inhibitory Control pada Informasi Tidak Relevan dan Area Otak yang Teraktivasi

\begin{tabular}{|c|c|c|c|}
\hline Penulis & Pengukuran & Subyek & Area Otak yang Teraktivasi \\
\hline Durston et al. (2002) & Go/No Go Test & $\begin{array}{l}\text { Anak dan } \\
\text { Dewasa }\end{array}$ & $\begin{array}{l}\text { Lobus frontalis dan parietalis } \\
\text { pada anak; dan sirkuit fronto- } \\
\text { striatal pada orang dewasa. }\end{array}$ \\
\hline Jaegar (2013) & $\begin{array}{l}\text { Anti saccade; } \\
\text { Go/No Go }\end{array}$ & Remaja & $\begin{array}{l}\text { Dorsolateral prefrontal cortex, } \\
\text { anterior cingulate cortex dan } \\
\text { area fronto-striatal }\end{array}$ \\
\hline Poirel et. al. (2012) & Stroop Task & Anak-anak & $\begin{array}{l}\text { The right insula dan inferior } \\
\text { frontal gyrus, di mana WM dgn } \\
\text { backward digit span } \\
\text { mengaktivasi intraparietal } \\
\text { sulcus. }\end{array}$ \\
\hline Triplett et al. (2014) & Antisaccade & $\begin{array}{l}\text { Anak dan } \\
\text { remaja }\end{array}$ & Left posterior cingulate gyrus \\
\hline He et al. (2019) & $\begin{array}{l}\text { Connectome- } \\
\text { based predictive } \\
\text { moodel }\end{array}$ & Dewasa & $\begin{array}{l}\text { Performansi tinggi inhibitory } \\
\text { control mengaktivasi otak area } \\
\text { ventromedial PFC dan left } \\
\text { middle temporal. }\end{array}$ \\
\hline $\begin{array}{l}\text { Pornpattananangkul et. al. } \\
\text { (2016) }\end{array}$ & Go/No-Go Task & Dewasa & $\begin{array}{l}\text { Anterior cingulate cortex dan } \\
\text { inferior frontal gyrus }\end{array}$ \\
\hline
\end{tabular}


Tabel 3 menginformasikan bahwa peran inhibitory control terhadap informasi tidak relevan mengaktivasi area otak korteks. Performansi menghambat informasi tidak relevan agar tidak mencemari informasi relevan ditunjukkan melalui peran proses kognitif tingkat tinggi. Namun, apakah aktivasi neural hanya ditunjukkan pada area korteks saja? Area subkorteks dalam hal ini juga terlibat, misalnya menampilkan emosi tertentu yang dimaknai sebagai reaksi emosi yang perlu dihambat. Interaksi antara ventromedial prefrontal cortex dan cortex amygdala adalah perwujudan dari inhibitory control yang terkait dengan reaksi emosi yang dimaksud (Dillon \& Pizzagalli, 2007). Disisi lain, pada tugas inhibitory control lebih banyak mengaktivasi area anterior cortex cingular yang mana area kortex ini merupakan sentral untuk koneksi area lain di otak terkait menghambat pikiran dan respons yang tidak diharapkan.

Berdasarkan uraian tersebut disimpulkan bahwa mekanisme neural inhibitory control pada informasi tidak relevan yakni mengaktivasi area prefrontal cortex (PFC) sebagai mekanisme neural yang mengeksekusi respons yang tepat tanpa tercemari oleh informasi tidak relevan. Area ventromedial merupakan sub-area dari PFC yang terkoneksi dengan amigdala berperan memberikan sinyal perintah agar meregulasi respons individu sehingga lebih adaptif. Anterior cingulate cortex terkoneksi dengan area lainnya pada korteks. Mekanisme neural inhibitory control yakni menghambat stimulus atau informasi tidak relevan dan respons yang tidak diharapkan melalui perintah prefrontal cortex kepada area subkorteks melalui anterior cingulate cortex. Constantinidis dan Luna (2019) melaporkan bahwa kapasitas inhibitory control semakin meningkat performansinya yang ditandai dengan aktivasi area otak dorsolateral prefrontal cortex dan dorsal anterior cingulate cortex. Hal tersebut mengindikasikan semakin meningkatnya kemampuan mempersiapkan respons, memproses error dan respons yang terencana. Adapun untuk mengetahui performansi tiga kemampuan tersebut diakukan pengukuran neuropsikologi, diantaranya: anti saccade dan stroop task (Finkelmeyer et.al., 2010; Jacqui et al., 2014; Macdonald et al., 2014).

\section{Pembahasan}

Studi literatur ini bertujuan menguraikan mengenai: pertama, peran working memory (WM) terhadap informasi tidak relevan. WM sesuai dengan fungsi utamanya adalah menyimpan dan memanipulasi informasi atau stimulus di dalam pikiran (mind). Namun, informasi atau stimulus tersebut sebelum diproses pada working memory (WM) saling berkompetisi dengan informasi tidak relevan pada atensi (Mertes et al., 2016). Atensi yang tinggi menyebabkan hanya informasi relevan saja yang diproses, disimpan sementara dan selanjutnya melakukan update dan maintenance (Vellage et al., 2016). Sistem kerja WM dibatasi oleh waktu dan memfokuskan atensi pada stimulus target (informasi relevan). Fokus perhatian yang makin lemah menghasilkan kesulitan merepresentasikan kembali stimulus target. Ini disebabkan oleh kembalinya bersaing antara informasi relevan dan tidak relevan pada atensi sebagaimana model mekanisme neural WM yang telah diuraikan sebelumnya. Simon et al. (2016) yang melaporkan bahwa atensi yang semakin 
meningkat saat pemrosesan informasi relevan "diganggu" oleh informasi yang tidak relevan. Performansi WM terhadap informasi tidak relevan yakni cukup ditandai dan diabaikan oleh WM (Fallon et al., 2018; Lilienthal et al., 2015).

Kesimpulannya bahwa peran working memory (WM) adalah memfokuskan atensi untuk memproses informasi relevan sehingga informasi tidak relevan terabaikan. Performansi WM individu salah satunya ditunjukkan melalui pengukuran tugas backward digit span (Pisoni \& Cleary, 2003; Waters \& Caplan, 2003). Tugas backward digit span memerlukan kontrol seleksi atensi (Oberauer, 2019). Kontrol seleksi atensi ditujukan pada stimulus-stimulus target dengan kata lain perhatian hanya difokuskan pada informasi relevan. Performansi working memory (WM) terhadap informasi tidak relevan cukup ditandai dan diabaikan saja. Kapasitas WM selama memproses stimulus sangat ditentukan oleh upaya memfokuskan atensi dalam durasi waktu yang singkat pada stimulus tersebut (Fabius et al., 2017; Howard et al., 2020). Performansi kapasitas WM mengalami penurunan jika atensi makin melemah dan upaya meningkatkan kembali fokus atensi dikarenakan munculnya kembali informasi tidak relevan. Perfomansi kapasitas WM semakin tinggi seiring dengan kemampuan memproses informasi relevan dan merepresentasikannya dengan tepat. Di sisi lain, informasi tidak relevan oleh WM tidak hanya sekadar ditandai atau diabaikan melainkan dihambat untuk kinerja WM yang lebih baik. Janowich et al. (2015) melaporkan bahwa kapasitas working memory dapat ditingkatkan melalui memproses stimulus atau informasi tidak relevan. Di dalam hal ini ada kapasitas kognitif lain yang memberi dukungan pada kinerja working memory yang lebih baik, yakni semakin meningkatkan kapasitas menampung informasi dan melakukan update. Salah satu contoh tugas backward digit span task di mana semakin banyak digit yang dapat direcall dengan tepat maka semakin tinggi kapasitas WM individu. Piotrowski et al. (2019) menguji dua hipotesis yakni, apakah informasi tidak relevan dihapus dari perhatian dalam sistem working memory atau menghambat stimulus tidak relevan. Studi yang mirip sebelumnya melaporkan bahwa informasi tidak relevan di dalam working memory tidak dihapus, melainkan terus ada berdampingan bersama informasi relevan (Yin et al., 2012). Temuan para ahli tersebut menyimpulkan bahwa working memory menampilkan performansi yang lebih baik dengan adanya usaha menghambat respons dari sistem kognitif. Kapasitas inhibitory control merupakan bagian dari sistem kognitif kontrol juga berperan sebagai seleksi atensi, khususnya memproses stimulus atau informasi tidak relevan (Neill et al., 1995; Veer et al., 2017). Hal ini dapat disimpulkan bahwa peran kapasitas working memory dalam menyimpan dan memanipulasi informasi atau stimulus target bergantung pada performansi inhibitory control dalam menghambat informasi tidak relevan.

Tujuan yang kedua adalah peran inhibitory control (IC) terhadap informasi tidak relevan. Berdasarkan pengukuran yang digunakan untuk menilai performansi IC antara lain: Go/No task (Luijten et al., 2011), antisaccade (Wilcockson et al., 2019) dan stroop task (West \& Alain, 2000) merupakan tes kognitif yang terdiri dari informasi tidak relevan diantara stimulus target atau informasi relevan. Tes tersebut mengukur kapasitas menghambat pikiran dan respons yang tidak diharapkan (karena interferensi) baik dalam 
latar akademik (Chamorro et al., 2017) maupun konteks perilaku sosial, misalnya pengambilan keputusan (Leontyev et al., 2018). Geng et al. (2005) melaporkan bahwa performansi IC bergantung pada bagaimana usaha IC tersebut menghambat stimulus dan respons yang tidak tepat (Xu et al., 2019). Hal yang dapat disimpulkan bahwa apakah semakin baik kualitas performansi IC maka semakin baik pula kualitas working memory (WM) dalam memfokuskan hanya pada informasi atau stimulus target saja. Blasiman dan Was (2018) dalam studinya mengidentifikasi 21 faktor yang menyebabkan performansi working memory tidak stabil. Riset lainnya melaporkan bahwa kapasitas working memory dapat ditingkatkan dengan melatih inhibitory control (Zhao et al., 2016). Inhibitory control (IC) sebagai pendukung performansi working memory dalam menghambat informasi tidak relevan. Hal yang berbeda dengan IC yang mana memfokuskan pada menghambat stimulus dan respons yang tidak diharapkan. WM pada kondisi tertentu efektif menandai dan mengabaikan informasi tidak relevan tanpa melibatkan IC ketika tugas memproses informasi relevan belum bersifat kompleks (Lv, 2015). Perspektif perkembangan antara IC dan WM menjelaskan mengenai kapan IC masih merupakan bagian dari WM. Dan, di waktu kapan inhibitory control bersifat independen atau terpisah dengan working memory. Riset terdahulu melaporkan bahwa ketika masa bayi sampai dengan masa anak awal inhibitory control dan working memory merupakan konsep unity selanjutnya menjadi diversity dengan tugas yang berbeda saat usia pertengahan anak sampai dengan remaja dan masa dewasa (Shing et al., 2010). Working memory dan inhibition control merupakan komponen dari executive function (EF) yang setara, yakni sama-sama mendukung proses kognitif yang kompleks dan saling independen satu sama lain, yaitu masing-masing memiliki tugas dan peran (Miyake \& Friedman, 2012; Miyake et al., 2000).

Kesimpulan yang dapat ditarik yakni working memory dan inhibitory control merupakan mekanisme kontrol kognitif dan saling independen satu dengan lainnya yang dimulai sejak masa pertengahan anak sampai dengan dewasa. Mekanisme performansi working memory pada kondisi tertentu dapat berperan tunggal selain meng-update dan memaintenance informasi juga memastikan bahwa informasi tidak relevan tidak turut dalam proses, yakni dengan cara menandai dan mengabaikan. Namun, semakin tinggi kapasitas working memory semakin menuntut tugas yang kompleks dan tantangan working memory semakin tinggi. Kapasitas working memory yang dimaksud tidak selalu menjamin bahwa kualitas performansinya baik dalam memproses informasi relevan saat tantangan mengabaikan informasi tidak relevan sulit dilakukan. Kondisi demikian mengijinkan tugas menghambat stimulus dan respons yang tidak diharapkan agar performansi working memory tidak mengalami beban yang berlebihan. Sifat informasi tidak relevan pada working memory tidak dihapus untuk tujuan menghindari beban berlebih namun dengan menandai dan mengabaikan. Hal ini sangat berpeluang informasi tidak relevan tersebut dapat muncul kembali memberikan interferensi.

Mekanisme neural yang mendasari kontrol informasi tidak relevan baik berdasarkan kinerja working memory maupun inhibitory control yakni prefrontal cortex, misalnya pada dorsolateral prefrontal cortex dan anterior cingulate cortex (Koizumi et al., 2018). Struktur cingulate cortex merupakan jembatan neural baik menghubungkan ke area 
prefrontal maupun ke sistem limbik. Semakin menuju arah anterior semakin melibatkan berpikir abstrak dan pengambilan keputusan logis (Lockwond \& Wittmann, 2018) dan semakin menuju arah posterior menghasilkan perilaku termotivasi (Pearson et al., 2011). Informasi tidak relevan yang mengganggu atensi berasal dari amigdala meningkatkan aktivasi medial prefrontal cortex dan anterior cingulate cortex sebagai indikasi bahwa kedua area tersebut melakukan kontrol terhadap stimulus tersebut (McRae et al., 2010). Hal ini juga menunjukkan bahwa kedua wilayah otak tersebut saling inter-koneksi secara topdown jika itu melibatkan peran terbesar prefrontal cortex dalam mengawasi kinerja otak subkorteks (Banks et al., 2007). Sistem neural yang terdapat di otak tidak memungkinkan bahwa fungsi neural tertentu berbeda secara terpisah dengan neural lainnya dalam melaksanakan tugas. Tugas tertentu dapat saja melibatkan beberapa sistem neural di otak, misalnya membaca mengaktivasi area otak korteks singulat dan lobus parietalis (Choi et al., 2014). Oleh karena itu kinerja working memory dan inhibitory control terhadap informasi tidak relevan dapat saja berada pada jalur mekanisme neural yang sama. Walaupun demikian, tidak berarti bahwa keduanya memiliki fungsi yang sama persis terhadap informasi tidak relevan maupun stimulus yang tidak dihendaki.

Berdasarkan uraian tersebut, baik working memory (WM) maupun inhibitory control (IC) keduanya memiliki peran pada informasi tidak relevan. Working memory mempertahankan informasi relevan untuk disimpan dan dimanipulasi serta mengabaikan informasi tidak relevan; sedangkan inhibitory control bekerja untuk menghambat stimulus dan respons tidak relevan atau tidak dikehendaki (Tiego et al., 2018). Dinamika antara working memory dan inhibitory control dapat terlihat ketika atensi terganggu oleh informasi tidak relevan. Karakteristik informasi tidak relevan menentukan upaya atensi, yakni ketika kapasitas working memory (WM) memproses tugas yang sangat kompleks hingga peran menandai dan informasi tidak relevan hampir tidak dapat dilakukan maka inhibitory control memberikan dukungannya (Keijzer, 2013; Woumans et al., 2019). Borella dan de Ribaupierre (2013) menegaskan melalui hasil penelitiannya bahwa peran penting mekanisme inhibitory control saat working memory memproses stimulus yang bertujuan menghindari beban berlebih pada memori tersebut.

Kondisi tertentu dimana sifat stimulus atau informasi tidak relevan hanya cukup untuk ditandai dan diabaikan saja oleh working memory. Hal ini diperkuat dengan hasil studi empirik para ahli ketika menguji peran working memory (WM) dan inhibitory control (IC) secara bersama pada tugas tertentu menghasilkan WM lebih kuat pengaruhnya dibanding IC (Linck \& Weiss, 2015; Pennequin et al., 2010). Disisi lain, kapasitas inhibitory control tidak bergantung pada kinerja working memory (El Massiouli, 2016; Pivnera et al., 2012).

\section{Penutup}

Working memory (WM) dan inhibitory control (IC) terlibat dalam proses berpikir tingkat tinggi dan terhadap informasi tidak relevan. Performansi kapasitas WM menandai dan mengabaikan informasi tidak relevan sementara menghambat dan respons tidak relevan 
dilakukan oleh inhibitory control. Mekanisme neural yang terlibat baik WM dan IC dalam merespons informasi tidak relevan relatif sama yakni mengaktivasi area prefrontal cortex sebagai neural penting pada kontrol kognitif. Area anterior cingulate cortex (ACC) merupakan neural yang menjadi penghubung baik lateral maupun medial prefrontal cortex untuk kontrol kogntif. ACC juga merupakan jalur neural yang terkait dengan tugas menghambat stimulus dan respons yang tidak dihendaki. Perfomansi kapasitas WM didukung oleh kinerja IC yang bergantung pada karakteristik informasi yang diproses oleh WM.

Implikasi studi literatur ini, yakni terkait dengan perkembangan otak yang dipengaruhi oleh karakteristik budaya kolektif masyarakat Indonesia. Budaya dan kebiasaan masyarakat kolektif cenderung mengaktivasi area otak kiri yang berdampak pada perkembangan verbal working memory lebih dominan dibandingkan visual working memory (Medina et al., 2019; Nakagawa et al., 2019). Karakteristik masyarakat timur, yakni di Indonesia yang lebih mendahulukan sikap malu, lebih menghargai dan menghormati orang yang lebih tua yang salah satunya terwujud dalam tata krama berbahasa daerah, misalnya bahasa Jawa biasa dan halus. Pembiasaan demikian melatih dan membentuk area otak anterior cingulate cortex (ACC) menjadi kuat (Pornpattanangkul et al., 2016). Anterior cingulate cortex (ACC) telah dilaporkan para ahli sebelumnya bahwa area otak ini berfungsi sebagai kontrol emosi dan kognitif yang ditunjukkan melalui performansi inhibitory control (Ivancovsky et al., 2018).

\section{Ucapan Terima Kasih}

Penulis menyampaikan terima kasih kepada para reviewer yang telah memberikan catatan-catatan perbaikan pada manuskrip ini.

\section{Pendanaan}

Penulisan manuskrip ini tidak didanai oleh sumber pendanaan pemerintah ataupun sumber pendanaan eksternal lainnya, selain dari penulis sendiri.

\section{Kontribusi Penulis}

NRS menemukan topik dan menuliskan keseluruhan dari isi manuskrip.

\section{Pernyataan Konflik Kepentingan}

Penulis menyampaikan bahwa tidak ada konflik kepentingan dalam penulisan manuskrip ini.

\section{Orcid ID}

Nani Restati Siregar https://orcid.org/0000-0002-0051-4437

\section{Daftar Pustaka}

Abdul Hamid, K., Yusoff, A. N., Rahman, S., Osman, S. S., Azmi, N. H., Surat, S., \& Ahmad Marzuki, M. (2019). Cortical differential responses during divergent thinking tasks after creativity stimulation. Psychology $\mathcal{E}$ Neuroscience, 12(3), 342-362. https://doi.org/10.1037/pne0000168 
Almaric, M., \& Dehaene, S. (2016). Origins of the brain networks for advanced mathematics in expert mathematicians. Proceedings of the National Academy of Science, 113(18), 4909-4917. https://doi.org/10.1073/pnas.1603205113

Ahveninen, J., Seidman, L. J., Chang, W-T., Hämäläinin, M., \& Huang, S. (2017). Suppression of irrelevant sounds during auditory working memory. Neurolmage, 161, 1-8. https://dx.doi.org/10.1016/j.neuroimage.2017.08.040

Arnsten, A. F. T., Raskind, M. A., Taylor, F. B., \& Connor, D. F. (2015). The effects of stress exposure on prefrontal cortex: Translating basic research into successful treatments for post-traumatic stress disorder. Neurobiology of Stress, 1, 89-99. https://doi.org/10.1016/j.ynstr.2014.10.002

Artuso, C., \& Palladino, P. (2019). Long-term memory effects on working memory updating development. PLoS ONE, 14(5), e0217697. https://doi.org/10.1371/journal.pone.0217697

Aydmune, Y., Introzzi, S., Zamora, E., \& Stelzer, F. (2019). Inhibiting processes and fluid intelligence: A performance at early years of schooling. International Journal of Psychological Research, 13(1), 29-39. https://doi.org/10.21500/20112084.4231

Baddeley, A. (2012). Working memory: Theories, models, and controversies. Annual Review of Psychology, 63, 1-29. https://doi.org/10.1146/annurev-psych-120710-100422

Baier, B., Karnath, H. O., Dietrich, M., Birklein, F., Heinze, C., \& Müller, N. (2010). Keeping memory clear and stable - The contribution of human basal ganglia and prefrontal cortex to working memory. Journal of Neuroscience, 30(29), 9788-9792. https://doi.org/10.1523/jneurosci.1513-10.2010

Banks, S. J., Eddy, K. T., Angstadt, M., Nathan, P. J., \& Phan, K. L. (2007). Amygdalafrontal connectivity during emotion regulation. Social cognitive and Affective Neuroscience, 2(4), 303-312. https://doi.org/10.1093/scan/nsm029

Blair, C., Knipe, H., \& Gamson, D. A. (2008). Is there a role for executive functions in the development of mathematics ability? Mind, Brain, and Education, 2(2), 80-89. https://doi.org/10.1111/j.1751-228X.2008.00036.x

Blasiman, R. N., \& Was, C. A. (2018). Why is working memory performance unstable? A review of 21 factors. Europe's Journal of Psychology, 14(1), 188-231. https://dx.doi.org/10.5964/ejop.v14i1.1472

Blumenfeld, H., \& Marian, V. (2014). Cognitive control in bilinguals: Advantages in stimulus-stimulus inhibition. Bilingualism: Language and Cognition, 17(3), 610-629. https://dx.doi.org/10.1017/S1366728913000564

Bocincova, A., \& Johnson, J. (2019). The time course of encoding and maintenance of taskrelevant versus irrelevant object features in working memory. Cortex, 111, 196-209. https://doi.org/10.1016/j.cortex.2018.10.013

Borella, E., \& de Ribaupierre, A. (2013). The role of working memory, inhibition, and processing speed in text comprehension in children. Learning and Individual Differences, 34, 86-92. https://doi.org/10.1016/j.lindif.2014.05.001 
Brookman-Byrne, A., Mareschal, D., Tolmie, A. K., \& Dumontheil, I. (2018). Inhibitory control and counterintuitive science and maths reasoning in adolescence. PloS ONE, 13(6), e0198973. https://doi.org/10.1371/journal.pone.0198973

Brooks, S. J., Funk, S. G., Young, S. Y., \& Schiöth, H. B. (2017). The role of working memory for cognitive control in anorexia nervosa versus substance use disorder. Frontiers in Psychology, 8, 1651. https://doi.org/10.3389/fpsyg.2017.01651

Brosch, T., Schiller, D., Mojdehbakhsh, R., Uleman, J. S., \& Phelps, E. A. (2013). Neural mechanisms underlying the integration of situational information into attribution outcome. Social Cognitive and Affective Neuroscience, 8(6), 640-646. https://doi.org/10.1093/scan/nst019

Burhan, A. M., Anazodo, U. C., Chung, J. K., Arena, A., Graff-Guerrero, A., \& Mitchell, D. G. V. (2016). The effect of task-irrelevant fearful-face distractor on WM processing in mild cognitive impairement versus healthy control: An exploratory fMRI study in female participants. Behavioral Neurology, 2016, 1637392. https://doi.org/10.1155/2016/1637392

Chamorro, Y., Treviño, M., \& Matute, E. (2017). Educational and cognitive predictors of pro- and antisaccadic performance. Frontiers in Psychology, 8, 2009. https://doi.org/10.3389/fpsyg.2017.02009

Choi, W., Desai, R. H., \& Henderson, J. M. (2014). The neural substrates of natural reading: A comparison of normal and nonword text using eyetracking and fMRI. Frontiers in Human Neuroscience, 8, 1024. https://doi.org/10.3389/fnhum.2014.01024

Chiappe, P., Hasher, L., \& Siegel, L. S. (2000). Working memory, inhibitory control, and reading disability. Memory \& Cognition, 28(1), 8-17. https://doi.org/10.3758/BF03211570

Clapp, W. C., Rubens, M. T., \& Gazzaley, A. (2010). Mechanisms of working memory disruption by external interference. Cerebral Cortex, 20(4), 859-872. https://doi.org/10.1093/cercor/bhp150

Constatinidis, C., \& Luna, B. (2019). Neural substrates of inhibiting control maturation in adolescence. Trends in Neuroscience, 42(9), 604-616. https://doi.org/10.1016/j.tins.2019.07.004

Cowan, N. (2014). Working memory underpins cognitive development, learning, and education. Educational Psychology Review, 26(2), 197-223. https://doi.org/10.1007/s10648-013-9246-y

Cowan, N., \& Morey, C. C. (2006). Visual working memory depends on attentional filtering. Trends in Cognitive Sciences, 10(4), 139-141. https://doi.org/10.1016/j.tics.2006.02.001

Crone, E.A., Wendelken, C., Donchve,S., \& van Leijenhorst, L. (2006). Neurocognitive development of the ability to manipulate information in working memory. Proceedings of the National Academy of Science, 103(24), 9315-9320. https://doi.org/10.1073/pnas.0510088103

De Houwer, J., Hughes, S., \& Barnes-Holmes, D. (2016). Associative learning as higher order cognition: Learning in human and nonhuman animals from the perspective of 
propositional theories and relational frame theory. Journal of Comparative Psychology, 130(3), 215-225. https://doi.org/10.1037/a0039999

Derrfuss, J., Ekman, M., Hanke, M., Tittgemeyer, M., \& Fiebach, C. J. (2017). Distractorresistant short-term memory is supported by transient changes in neural stimulus representations. Journal of Cognitive Neuroscience, 29(9), 1547-1565. https://doi.org/10.1162/jocn a 01141

Dillon, D. G., \& Pizzagalli, D. A. (2007). Inhibition of action, thought, and emotion: A selective neurobiological review. Applied \& Preventive Psychology, 12(3), 99-114. https://doi.org/10.1016/j.appsy.2007.09.004

Durston, S., Thomas, K. M., Yang, Y., Ulug, A. M., Zimmerman, R. D., \& Casey, B. J. (2002). A neural basis for the development of inhibitory control. Developmental Science, 5(4), F9-F16. https://doi.org/10.1111/1467-7687.00235

Egner, T., Elano, M., \& Hirsch, J. (2006). Separate conflict-specific cognitive control mechanisms in the human brain. Neuroimage, 35(2), 940-948. https://doi.org/10.1016/j.neuroimage.2006.11.061

El Massioui, N., Lamirault, C., Yagüe, S., Adjeroud, N., Garces, D., Maillard, A.,...\& Doyère, V. (2016). Impaired decision making and loss of inhibitory-control in a rat model of Huntington disease. Frontiers in Behavioral Neuroscience, 10, 204. https://doi.org/10.3389/fnbeh.2016.00204

Endres, M. J., Houpt, J. W., Dunkin, C., \& Fin, P. R. (2015). Working memory capacity and redundant information processing efficiency. Frontiers in Psychology, 6, 594, https://dx.doi.org/10.3389/fpsyg.2015.00594

Eriksson, J., Vogel, E. K., Lansner, A., Bergström, F., \& Nyberg, L. (2015). Neurocognitive architecture of working memory. Neuron, 88(1), 33-46. https://doi.org/10.1016/j.neuron.2015.09.020

Fabius, J. H., Mathôt, S., Schut, M. J., Nijboer, T. C. W., \& der Stigchel, S. V. (2017). Focus of spatial attention during spatial working memory maintenance: Evidence from pupillary light response. Visual Cognition, 25(1-3), 10-20. https://doi.org/10.1080/13506285.2017.1311975

Fallon, S. T., Dolfen, N., Parolo, F., Zokei, N., \& Husain, M. (2019). Task-irrelevant financial losses inhibit the removal of information from working memory. Scientific Reports, 9, 1673. https://doi.org/10.1038/s41598-018-36826-x

Fallon, S. T., Mattiesing, R. M., Dolfen, N., Manohar, S. G., \& Husain, M. (2018). Ignoring versus updating in working memory reveal differential roles of attention and feature binding. Cortex, 107, 50-63. https://doi.org/10.1016/j.cortex.2017.12.016

Fastame, M. C. (2020). Visual and spatial working memory skills implicated in copying and drawing from memory of The Rey-Osterrieth Complex Figure. What relationship in the school-aged children? Cognitive Development, 53, 100826. https://doi.org/10.1016/j.cogdev.2019.100826

Finkelmeyer, A., Kellerman, T., Bude, D., Nießen, T., Schwenzer, M., Mathiak, K., \& Reske, M. (2010). Effects of aversive odour presentation on inhibitory control in the stroop colour-word interference task. BMC Neuroscience, 11, 131. 
https://doi.org/10.1186/1471-2202-11-131

Gaspelin, N., \& Luck, S. J. (2018). The role of inhibition in avoiding distraction by salient stimuli. Trends in Cognitive Sciences, 22(1), 79-92. https://doi.org/10.1016/j.tics.2017.11.001

Geng, H., Song, Q., Li, Y., \& Zhu, Y. (2005). The effect of attention to distractor on inhibitory process in selective attention. Chinese Science Bulletin, 50(16), 1743-1750. https://doi.org/10.1360/982005-516

Greiff, S., Wüstenberg, S., Goetz, T., Vainikainen, M. P., Hautamäki, J., \& Bornstein, M. H. (2015). A longitudinal study of higher-order thinking skills: working memory and fluid reasoning in childhood enhance complex problem solving in adolescence. Frontiers in Psychology, 6, 1060. https://doi.org/10.3389/fpsyg.2015.01060

He, N., Rolls, E. T., Zhao, W., \& Guo, S. (2019). Predicting human inhibitory control from brain structural fMRI. Brain Imaging and Behavior, 14(6), 2148-2158. https://doi.org/10.1007/s11682-019-00166-9

Heathcote, A., Coleman, J. R., Eidels, A., Watson, J. M., Houpt, J., \& Strayer, D. L. (2015). Working memory's workload capacity. Memory \& Cognition, 43, 973-989. https://doi.org/10.3758/s13421-015-0526-2

Howard, C. J., Pole, R., Montgomery, P., Woodward, A., Guest, D., Standen, B.,...\&\& Crowe, E. M. (2020). Visual spatial attention and spatial working memory do not draw on shared capacity-limited core processes. Quarterly Journal of Experimental Psychology, 73(5), 799-818. https://doi.org/10.1177/1747021819897882

Huang, J., Kahana, M. J., \& Sekuler, R. (2009). A task-irrelevant stimulus attribute affects perception and short-term memory. Memory \& Cognition, 37(8), 1088-1102. https://doi.org/10.3758/MC.37.8.1088

Ivancovsky, T., Kleinmintz, O., Lee, J., Kurman, J., \& Shamay-Tsoory, S. G. (2018). The neural underpinings of cross-cultural differences in creativity. Human Brain Mapping, 39(11), 4493-4508. https://doi.org/10.1002/hbm.24288

Jacqui, A. M., Miriam, H. B., Judith, A. C., \& Peter, J. A. (2014). Age-related differences in inhibitory control in the early school years. Child Neuropsychology, 20(5), 509-526. https://doi.org/10.1080/09297049.2013.822060

Jaeger, A. (2013). Inhibitory control and the adolescent brain: A review of fMRI research. Psychology \& Neuroscience, 6(1), 23-30. http://dx.doi.org/10.3922/j.psns.2013.1.05

Janowich, J., Mishra, J., \& Gazzaley, A. (2015). A cognitive paradigm to investigate interference in working memory by distractions and interruptions. Journal of Visualized Experiments, 101, e52226. https://doi.org/10.3791/52226

Karlsson, J., Jolles, D., Koornneef, A., van den Broek, P., \& Leijenhorst, L.V. (2019). Individual differences in children's comprehension of temporal relation: Dissociable contributions of working memory capacity and working memory updating. Journal of Experimental Child Psychology, 185, 1-18. https://doi.org/10.1016/j.jecp.2019.04.007

Keijzer M. (2013). Working memory capacity, inhibitory control and the role of L2 proficiency in aging L1 Dutch speakers of near-native L2 English. Brain Sciences, 3(3), 1261-1281. https://doi.org/10.3390/brainsci3031261 
Kesler, S. R., Sheau, K., Koovakkattu, D., \& Reiss, A. L. (2011). Changes in frontal-parietal activation and math skills performance following adaptive number sense training: preliminary results from a pilot study. Neuropsychological Rehabilitation, 21(4), 433454. https://doi.org/10.1080/09602011.2011.578446

Koizumi, A., Lau, H., Shimada, Y., \& Kondu, H.M. (2018). The effect neurochemical balance in the anterior cingulate cortex and dorsolateral prefrontal cortex on volitional control under irrelevant distraction. Consciousness and Cognition, 59, 104111. https://doi.org/10.1016/j.concog.2018.01.001

Künstler, E., Finke, K., Günther, A., Klingner, C., Witte, O., \& Bublak, P. (2018). Motorcognitive dual-task performance: Effects of a concurrent motor task on distinct components of visual processing capacity. Psychological Research, 82(1), 177-185. https://doi.org/10.1007/s00426-017-0951-x

Laing, P. A. F., Burns, N., \& Baetu, I. (2019). Individual differences in anxiety and fear learning: The role of working memory capacity. Acta Psychologia, 193, 42-54. https://doi.org/10.1016/j.actpsy.2018.12.006

Leontyev, A., Sun, S., Wolfe, M., \& Yamauchi, T. (2018). Augmented go/no-go task: Mouse cursor motion measures improve ADHD symptom assessment in healthy college students. Frontiers in Psychology. 9, 496. https://doi.org/10.3389/fpsyg.2018.00496

Lilienthal, L., Rose, N. S., Tamez, E., Myerson, J., \& Hale, S. (2015). Individuals with low working memory spans show greater interference from irrelevant information because of poor source monitoring, not greater activation. Memory $\mathcal{E}$ Cognition, 43(3), 357-366. https://doi.org/10.3758/s13421-014-0465-3

Linck, J. A., \& Weiss, D. J. (2015). Can working memory and inhibitory control predict second language learning in the classroom? SAGE Open, 5(4), 1-11. https://doi.org/10.1177/2158244015607352

Little, D. R., Lewandowsky, S., \& Craigg, S. (2014). Working memory capacity and fluid abilities: The more difficult the item, the more is better. Frontiers in Psychology, 5, 239. https://doi.org/10.3389/fpsyg.2014.00239

Lockwond, P. L., \& Wittmann, M. K. (2018). Ventral anterior cingulate cortex and social decision-making. Neuroscience $\mathcal{E} \quad$ Biobehavioral Reviews, 92, 187-191. https://doi.org/10.1016/j.neubiorev.2018.05.030

Luck, S. T., \& Vogel, E. K. (2013). Visual working memory capacity: from psychophysics and neurobiology to individual differences. Trends in Cognitive Science, 17(8), 391400. https://doi.org/10.1016/j.tics.2013.06.006

Luijten, M., Littel, M., \& Franken, I. H. A. (2011). Deficits in inhibitory control in smokers during a go/nogo task: An investigation using event-related brain potentials. PLoS ONE, 6(4), e18898. https://dx.doi.org/10.1371/journal.pone.0018898

Lustig, C., Hasher, L., \& Tonev, S. T. (2001). Inhibitory control over the present and the past. European Journal of Cognitive Psychology, 13(1-2), 107-122. https://doi.org/10.1080/09541440126215 
Lv, K. (2015). The involvement of working memory and inhibition functions in the different phases of insight problem solving. Memory $\mathcal{E}$ Cognition, 43, 709-722. https://doi.org/10.3758/s13421-014-0498-7

Macdonald, J. A., Beauchamp, M. H., Crigan, J. A., \& Anderson, P. J. (2014). Age-related differences in inhibitory control in the early school years. Child Neuropsychology, 20(5), 509-526. https://doi.org/10.1080/09297049.2013.822060

Manza, P., Hau, C, L, H., \& Leung, H-C. (2014). Alpha power gates relevant information during working memory updating. Journal of Neuroscience, 34(17), 5998-6002. https://doi.org/10.1523/JNEUROSCI.4641-13.2014

Maraver, M. J., Bajo, M. T., \& Gomez-Ariza, C. J., (2016). Training on working memory and inhibitory control in young adults. Frontiers in Human Neuroscience, 10, 588. https://doi.org/10.3389/fnhum.2016.00588

Martyr, A., Boycheva, E., \& Kudlicka, A. (2019). Assessing inhibitory control in early-stage Alzheimer's and Parkinson's disease using the Hayling Sentence Completion Test. Journal of Neuropsychology, 13(1), 67-81. https://doi.org/10.1111/jnp.12129

McRae, K., Hughes, B., Chopra, S., Gabrieli, J. D., Gross, J. J., \& Ochsner, K. N. (2010). The neural bases of distraction and reappraisal. Journal of Cognitive Neuroscience, 22(2), 248-262. https://doi.org/10.1162/jocn.2009.21243

Medina, L. D., Sadler, M., Yeh, M., Filoteo, J. V., Woods, S. P., \& Gilbert, P. E. (2019). Collectivism is associated with greater neurocognitive fluency in older adults. Frontiers in Human Neuroscience, 13, 122. https://doi.org/10.3389/fnhum.2019.00122

Mertes, C., Wascher, E., \& Schneider, D. (2016). From capture to Inhibition: How does irrelevant information influence visual search? Evidence from a spatial cuing paradigm. Frontiers in Human Neuroscience, 10, 232. https://dx.doi.org/10.3389/fnhum.2016.00232

Meyer, H. C., \& Bucci, D. J. (2016). Neural and behavioral mechanisms of proactive and reactive inhibition. Learning Memory, 23(10), 504-514. https://doi.org/10.1101/1m.040501.115

Michal, A. L., Lleras, A., \& Beck, D. M. (2014). Relative contributions of task-relevant and task-irrelevant dimensions in priming of pop-out. Journal of Vision, 14(12), 14. https://doi.org/10.1167/14.12.14

Milham, M. P., Erickson, K. I., Banich, M. T., Kramer, A. F., Webb, A., Wszalea, T., \& Cohen, N. T. (2002). Attentional control in the aging brain: Insight from an fMRI study of the stroop task. Brain and Cognition, 49(3), 277-296. https://doi.org/10.1006/brcg.2001.1501

Miyake, A., \& Friedman, N. P. (2012). The nature and organization of individual differences in executive functions: Four general conclusions. Current Directions in Psychological Science, 21(1), 8-14. https://doi.org/10.1177/0963721411429458

Miyake, A., Friedman, N. P., Emerson, M. J., Witzki, A. H., \& Howerter, A. (2000). The unity and diversity of executive function and their contributions to complex "frontal lobe" tasks: A latent variable analysis. Cognitive Psychology, 41, 49-100. https://doi.org/10.1006/cogp.1999.0734 
Moehring, A., Schroeders, U., \& Wilhelm, O. (2018). Knowledge is power for medical assistants: Crystallized and fluid intelligence as predictors of vocational knowledge. Frontiers in Psychology, 9, 28. https://doi.org/10.3389/fpsyg.2018.00028

van Moorselar, D., \& Slagter, H. A. (2019). Learning what is irrelevant or relevant: Expectations facilitate distractor inhibition and target facilitation through distinct neural mechanisms. Journal of Neuroscience, 39(35), 6953-6967. https://doi.org/10.1523/INEUROSCI.0593-19.2019

Na, D. G., Ryu, J. W., Byun, H. S., Choi, D. S., Lee, E. J., Chung, W. I., ... Han, B. K. (2000). Functional MR imaging of working memory in the human brain. Korean Journal of Radiology, 1(1), 19-24. https://doi.org/10.3348/kjr.2000.1.1.19

Nakagawa, S., Takeuchi, H., Taki, Y., Nouchi, R., Kotozaki, Y., Shinada, T., ...., \& Kawashima, R. (2019). Mean diffusity related collectivism among university students in Japan. Scientific Reports, 9, 1338. https://doi.org/10.1038/s41598-01837995-5

Nasr, S., Moeeny, A., \& Esteky, H. (2008). Neural correlate of filtering of irrelevant information from visual working memory. PLoS One, 3(9), e3282. https://doi.org/10.1371/journal.pone.0003282

Neill, W. T., Valdes, L. A., \& Terry, K. M. (1995). Selective attention and the inhibitory control of cognition. Dalam F. N. Dempster \& C. J. Brainerd (Eds.), Interference and Inhibition in Cognition (hal. 207-261). Academic Press.

Noreen, S., \& MacLeod, M. D. (2015). What do we really know about cognitive inhibition? Task demands and inhibitory effects across a range of memory and behavioural tasks. PloS One, 10(8), e0134951. https://doi.org/10.1371/journal.pone.0134951

Oberauer, K. (2019). Working memory and attention - A conceptual analysis and review. Journal of Cognition, 2(1), 36. http://doi.org/10.5334/joc.58

Oswald, J. P., Trembly, S., \& Jones, D. M. (2000). Disruption of comprehension by the meaning of irrelevant sound. Memory, 8(5), 345-350. https://doi.org/10.1080/09658210050117762

Pearson, J. M., Heilbronner, S. R., Barack, D. L., Hayden, B. Y., \& Platt, M. L. (2011). Posterior cingulate cortex: Adapting behavior to a changing world. Trends in Cognitive Sciences, 15(4), 143-151. https://dx.doi.org/10.1016/j.tics.2011.02.002

Pennequin, V., Sorel, O., \& Mainguy, M. (2010). Metacognition, executive functions and aging. The effect of training in the use of metacognitive skills to solve mathematical word problems. Journal of Adult Development, 17, 168-176. https://doi.org/10.1007/s10804-010-9098-3

Pimperton, H., \& Nation, K. (2010). Suppressing irrelevant information from working memory: Evidence for domain-specific deficits in poor comprehenders. Journal of Memory and Language, 62(4), 380-391. https://doi.org/10.1016/j.jml.2010.02.005

Piotrowski, K. T., Orzechowski, J., \& Stettner, Z. (2019). The nature of inhibition in working memory search task. Journal of Cognitive Psychology, 31(3), 285-302. https://doi.org/10.1080/20445911.2019.1591421

Pisoni, D. B., \& Cleary, M. (2003). Measures of working memory span and verbal 
rehearsal speed in deaf children after cochlear implantation. Ear and Hearing, 24(1 Suppl), 106S-20S. https://doi.org/10.1097/01.aud.0000051692.05140.8e

Plancher, G., Gyselinck, V., \& Piolino, P. (2018). The integration of realistic episodic memories relies on different working memory processing: Evidence from virtual navigation. Frontiers in Psychology, 9, 47. https://dx.doi.org/10.3389/fpsyg.2018.00047

Poirel N, Borst G, Simon G, Rossi S, Cassotti M, Pineau A, ...., Houdé, O. (2012). Number conservation is related to children's prefrontal inhibitory control: An fMRI study of a Piagetian task. PLoS One, 7(7): e40802. https://doi.org/10.1371/journal.pone.0040802

Polk, T. A., Drake, R. M., Jonides, J. J., Smith, M. R., \& Smith, E. E. (2008). Attention enhances the neural processing of relevant features and suppresses the processing of irrelevant features in humans: A functional magnetic resonance imaging study of the Stroop task. Journal of Neuroscience, 28(51), 13786-13792. https://dx.doi.org/10.1523/JNEUROSCI.1026-08.2008

Pornpattananangkul, N., Hariri, A. R., Harada, T., Mano, Y., Komeda, H., Parrish, T. B., ....\& Chiao, J. Y. (2016). Cultural influences on neural basis of inhibitory control. Neuroimage, 139, 114-126. https://doi.org/10.1016/j.neuroimage.2016.05.061

Pretto, M. P., Hartmann, L., Garcia - Burgos, D., Sallard, E., \& Spierer, L. (2019). Stimulus reward value interacts with training-induced plasticity in inhibitory control. Neuroscience, 421, 82-94. https://doi.org/10.1016/j.neuroscience.2019.10.010

Preuss, H., Leister, L., Pinnow, M., \& Legenbauer, T. (2019). Inhibitory control pathway to disinhibited eating: A matter of perspective. Appetite, 141, 104297. https://doi.org/10.1016/j.appet.2019.05.028

Roets, A., Hiel, A. V., Cornelis, I., \& Soetans, B. (2008). Determinants of task performance and invested effort: A need for closure by relative cognitive capacity interaction analysis. Personality and Social Psychology Bulletin, 34(6), 779-792. https://doi.org/10.1177/0146167208315554

Rolls, E. T. (2019). The cingulate cortex and limbic system for emotion, action and memory. Brain, Structure and Function, 224(9), 3001-3018. https://doi.org/10.1007/s00429-019-01945-2

Rop, G., van Wermeskerken, M., de Nooijer, J.A., Verkoeijen, P. P. J. L., \& van Goget, T. (2018). Task experience as a boundary condition for the negative effects of irrelevant Information on learning. Journal Educational Review, 30, 229-253. https://doi.org/10.1007/s10648-016-9388-9

Roos, L. E., Knight, E. L., Beauchamp, K. G., Berkman, E. T., Faraday, K., Hyslop, K., \& Fisher, P. A. (2017). Acute stress impairs inhibitory control based on individual differences in parasympathetic nervous system activity. Biological Psychology, 125, 58-63. https://doi.org/10.1016/j.biopsycho.2017.03.004

Rudner, M., \& Rönnberg, J. (2008). The role of episodic buffer in working memory for language processing. Cognitive Processing, 9(1), 19-28. https://doi.org/10.1007/s10339$\underline{007-0183-x}$

Sasaki, T. (2009). The role of the central executive in associative learning. Psychologia, 52, 80-90. 
Schilling, C., Kühn, S., Paus, T., Romanowski, A., Banaschewski, T., Barbot, A., ...., \& the IMAGEN consortium (2013). Cortical thickness of superior frontal cortex predicts impulsiveness and perceptual reasoning in adolescence. Molecular Psychiatry, 18(5), 624-630. https://doi.org/10.1038/mp.2012.56

Schurgin, M. W., Cunningham, C.A., Egeth, H. E., \& Brady,T. F. (2018). Visual long-term memory can replace active maintenance in visual working memory. bioRxiv, 38184. https://doi.org/10.1101/381848

Shah, P., \& Miyake, A. (1999). Models of working memory: An introduction. Dalam P. Shah, \& A. Miyake, (Eds). Models of Working Memory (hal.1-27). Cambridge University Press.

Shing, Y. L., Lindenberger, U., Diamond, A., Li, S. C., \& Davidson, M. C. (2010). Memory maintenance and inhibitory control differentiate from early childhood to adolescence. Developmental Neuropsychology, 35(6), 679-697. https://dx.doi.org/10.1080/87565641.2010.508546

Siebert, P. S., \& Ellis, H. C. (1991). Irrelevant thoughts, emotional mood styles, and cognitive task performance. Memory \& Cognition, 19, 507-513. https://doi.org/10.3758/BF03199574

Simon, S. S., Tusch, E. S., Holcomb, P. J., \& Daffner, K. R. (2016). Increasing working memory load reduces processing of cross-modal task-irrelevant stimuli even after controlling for task difficulty and executive capacity. Frontiers in Human Neuroscience, 10, 380. https://doi.org/10.3389/fnhum.2016.00380

Singh, K. A., Gignac, G. E., Brydges, C. R., \& Ecker, U.K.H. (2018). Working memory capacity mediates the relationship between removal and fluid intelligence. Journal of Memory and Language, 101, 18-36. https://doi.org/10.1016/j.jml.2018.03.002

Starr, D. A. (2011). Prefrontal-hippocampal pathways underlying inhibitory control over $\begin{array}{lllll}\text { memory. } & \text { Physiology } & \text { E } & \text { Behavior, } & 17(1),\end{array}$ https://doi.org/10.1016/j.nlm.2015.11.008

Strobel, B., Lindner, M.A., Saß, S., \& Köller, O. (2018). Task-irrelevant data impair processing of graph reading tasks: An eye tracking study. Learning and Instruction, 55, 139-147. https://doi.org/10.1016/j.learninstruc.2017.10.003

Swanson, H. L. (2016). Word problem solving, working memory and serious math difficulties: Do cognitive strategies really make a difference? Journal of Applied Research in Memory and Cognition, 5(4), 368-383. https://doi.org/10.1016/j.jarmac.2016.04.012

Swanson, H.L. (2015). Cognitive strategy interventions improve word problem solving and working memory in children with math disabilities. Frontiers in Psychology, 6, 109. https://dx.doi.org/10.3389/fpsyg.2015.01099

Swanson, H. L., Lussier, C. M., \& Orosco, M. J. (2013). Cognitive strategies, working memory, and growth in word problem solving in children with math difficulties. Journal of Learning Disabilities, 48(4), 339-358. https://doi.org/10.1177/0022219413498771

Swanson, H. L., Moran., A. S., Bocian., K., Lussier, C., \& Zheng, X. (2012). Generative 
strategies, working memory and word problem solving accuracy in children at risk for math disabilities. Learning Disabilities Quarterly, 36(4), 202-214. https://doi.org/10.1177/0731948712464034

Tiego, J., Testa, R., Bellgrove, M. A., Pantelis, C., \& Whittle, S. (2018). A hierarchical model of inhibitory control. Frontiers in Psychology, 9, 1339. https://doi.org/10.3389/fpsyg.2018.01339

Toepper, M., Gebhardt, H., Bebio, T., Thomas, C., Driessen, M., Bischoff, M.,...\& Sammer, G. (2010). Functional correlates of distractor suppression during spatial working $\begin{array}{llll}\text { memory encoding. } & \text { Neuroscience, } & 165(4), & 1244-1253 .\end{array}$ https://doi.org/10.1016/j.neuroscience.2009.11.019

Triplett, R. L., Velannova, K., Luna, B., Padmanathan, A., Gaillard, M. D., \& Asato, M. R. (2014). Investigating inhibitory control in children with epilepsy: An fMRI study. Epilepsia, 55(10), 1667-1676. https://doi.org/10.1111/epi.12768

Vara, A. S., Pang, E. W., Vidal, J., Anagnostou, E., \& Taylor, M. J. (2014). Neural mechanisms of inhibitory control continue to mature in adolescence. Developmental Cognitive Neuroscience, 10, 129-139. https://doi.org/10.1016/j.dcn.2014.08.009

Valle,T. M., Gómez-Ariza, C. J., \& Bajo, M.T. (2019). Inhibitory control during selective retrieval may hinder subsequent analogical thinking. PLoS One, 14(2), e0211881. https://doi.org/10.1371/journal.pone.0211881

Veer, I. M., Luyten, H., Mulder, H., van Tuijl, C., \& Sleegers, P. J. C. (2017). Selective attention relates to the development of executive functions in 2.5- to 3-year-olds: A longitudinal study. Early Childhood Research Quarterly, 41, 84-94. https://doi.org/10.1016/j.ecresq.2017.06.005

Vellage, A. K., Becke, A., Strumpf, H., Baier, B., Schönfeld, M. A., Hopf, J. M., \& Müller, N. G. (2016). Filtering and storage working memory networks in younger and older age. Brain and Behavior, 6(11), e00544. https://dx.doi.org/10.1002/brb3.544

Wais, P. E., \& Gazzaley, A. (2011). The impact of auditory distraction on retrieval of visual memories. Psychonomic Bulletin \& Review, 18(6), 1090-1097. https://doi.org/10.3758/s13423-011-0169-7

Waters, G., \& Caplan, D. (2003). The reliability and stability of verbal working memory measures. Behavior Research Methods, Instruments \& Computer, 35(4), 550-564. https://doi.org/10.3758/BF03195534

Wei, P., Yu, H., Müller, H. J., Pollman, S., \& Zhou, X. (2018). Differential brain mechanism for processing distracting information in task - relevant and irrelevant dimensions in visual search. Human Brain Mapping, 40(1), 110-124. https://doi.org/10.1002/hbm.24358

West, R., \& Alain, C. (2000). Age-related decline in inhibitory control contributes to the increased Stroop effect observed in older adults. Psychophysiology, 37(2), 179-189. https://doi.org/10.1111/1469-8986.3720179

Wilcockson, T. D. W., Mardanbegi, D., Sawyer, P., Gellersen, H., Xia, B., \& Crawford, T. J. (2019). Oculomotor and inhibitory control in dyslexia. Frontiers in Systems Neuroscience, 12, 66. https://doi.org/10.3389/fnsys.2018.00066 
Wilhelm, O., Hildebrandt, A., \& Oberauer, K. (2013). What is working memory capacity, and how can we measure it? Frontiers in Psychology, 4, 433. https://doi.org/10.3389/fpsyg.2013.00433

Woumans, E., Ameloot, S., Keuleers, E., \& Van Assche, E. (2019). The relationship between second language acquisition and nonverbal cognitive abilities. Journal of Experimental Psychology: General, 148(7), 1169-1177. https://doi.org/10.1037/xge0000536

Xu, K. S., Mayse, J. D., \& Courtney, M. S. (2019). Evidence for selective adjustments of inhibitory control in variant of the stop signal task. Quarterly Journal of Experimental Psychology, 72(4), 818-831. https://doi.org/10.1177/1747021818768721

Yamagato, S., Yamaguchi, S., \& Kobayashi, S. (2004). Impaired novelty processing in apathy after subcortical stroke. Stroke, 35(8), 1935-1940. https://doi.org/10.1161/01.str.0000135017.51144.c9

Yang, Z., \& Tang, A. C. (2011). Novelty-induced enhancement in spatial memory: Is infancy critical period?. Behavioral Brain Research, 219(1), 47-54. https://doi.org/10.1016/j.bbr.2010.12.020

Yin, J., Zhou, J., Xu, H., Liang, J., Gao, Z., \& Shen, M. (2012). Does high memory load kick task-irrelevant information out of visual working memory? Psychonomic Buletin $\mathcal{E}$ Review, 19, 218-224. https://doi.org/10.3758/s13423-011-0201-y

Zanto, T. P., \& Gazzaley, A. (2009). Neural suppression of irrelevant information underlies optimal working memory performance. Journal of Neuroscience, 29(10), 3059-3066. https://doi.org/10.1523/INEUROSCI.4621-08.2009

Zeinti, M., \& Kliegel, M. (2007). The role of inhibitory control in age - related operation span performance. European Journal of Ageing, 4(4), 213-217. https://dx.doi.org/10.1007/s10433-007-0066-0

Zelazo, P. D., \& Lee, W. S. C. (2010). Brain development: An overview. Dalam R. M. Lerner \& W. F. Overton (Eds.), The Handbook of Life-span development, volume 1: Cognition, biology, and methods, (hal.89-114). Wiley.

Zhang, L., Yu, S., Li, B., \& Wang, J. (2017). Can students identity the relevant information to solve the problem?. Journal of Educational Technology E Society, 20(4), 288-299.

Zhao, X., Chen, L., \& Maos, J. H. R. (2016). Training and transfer effect of response inhibition training in children and adults. Development Science, 21(1), e12511. https://doi.org/10.1111/desc.12511 